\title{
Construction and Validation of Students' Representations Questionnaire of Sport (SRQS)
}

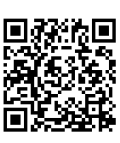

\author{
Chawki Derbalii ${ }^{1 *}$, Fathi Matoussi ${ }^{2}$ and Ali Elloumi ${ }^{3}$ \\ ${ }^{1}$ University of Jendouba, Tunisia \\ ${ }^{2}$ Virtual University of Tunis, Tunisia \\ ${ }^{3}$ University of Paris Descartes, France
}

Submission: June 21, 2019; Published: July 19, 2019

"Corresponding author: Chawki Derbali, Ph.D., University of Jendouba, Tunisia

\begin{abstract}
The purpose of the present investigation is to evaluate the psychometric properties of the French version of the Students' Representations Questionnaire of Sport (SRQS). It aims to construct and validate a Questionnaire for teenager Students designed to assess the extent of their representations to practice the sport of pole vaulting in educational environment. For this purpose, the SRQS was applied to 361 students (175 girls and 186 boys; age ranges between 15 and 18 years) participated in our study. The Confirmatory Factor Analysis showed that the French Questionnaire SRQS maintains good psychometric properties, supporting the representation of students for the practice of pole vault sport at school. Regarding factor analysis, the correlations between the Questionnaire subscales were accepted; internal consistencies were good; and the pole vault interest indexes were consistent with previous researches. Therefore, it is concluded, that the findings corroborate the application of SRQ-S as a psychometric useful measure of the students' representations of the practice of pole vault sport in educational setting, highlighting its validity and reliability. The integration of Pole Vaulting in physical education might be a gain.
\end{abstract}

Keywords: Validation; Questionnaire; Representations; Assessment; Students; Sport

\section{Introduction}

The concept of representation undertakes a position in social psychology and perception of sports activities. This notion was developed and assigned by Durkheim in his social psychology study as a concept of individual and collective representations. The theory of social representation might be able to offer a creative approach for studying how the school and sports' culture construct collective and educational issues. Indeed, Moscovici [1] examined the method in which scholarly discourse is transformed into a commonsense discourse. It means the system path from theoretical concepts to representations. In psychosocial investigate, quantitative study process is suitable when authentic data are requisite to answer the research inquiry of perceptions, attitudes, representation, beliefs and preferences [2]. Whereas, qualitative methods are used to reply issue concerning experience, meaning and perspective as a point view of the contributor, answering to concerns with 'what' 'why' and 'how' questions rather than 'how many $[3,4]$. For example, the good questionnaire should present the design which depends on whether the researcher needs to collect exploratory information as qualitative information for the issues of enhanced understanding or the generation of hypotheses on a topic or quantitative information to examine specific hypotheses that have been operationalized before.

A gradual number of studies are beginning to indicate that students' representations of different educational topics can collaborate to shed light on how the teaching of these topics may be more meaningful [5] as well as educators' conception [6,7] and psychometric properties for sport [8]. The study that will be described here will be concerned with student's representations of interest in the practice of pole vaulting in school environments. So, the need of doing this research is to understand the nature of the student's awareness of the sport activity and provides answers to the current problematic. It was aimed at understanding participant belief or attitude that has been tested for validity and reliability. There have been limited studies to investigate the importance of representation assessment on new adopted sport of performance for its implementation in physical education program. This questionnaire or tool might be providing baseline data of students' level on physical education and would help to identify types of representation that students are still lacking. 
Representations of Students to The Practice of Pole Vault Sport

The purpose of this study was twofold:

a. Construct a French version of a questionnaire determining five students' representations scales, for the integration of the sport of pole vaulting into the educational environment.

b. To study the exploratory analysis through the factorial structure of the questionnaire, the internal consistency and the correlations between the determined variables.

\section{Study 1}

Participants and procedure

The number of participants for this study is 147 volunteers (83 girls and 74 boys), aged between 15 and 18 years old. They attend permanent EPS courses. They are informed that the questionnaire is anonymous and that it is not a test. Each student must mention their age and gender for the interest of the research. All data remains confidential. Participants are asked to complete the questionnaire for a period of 10 to 15 minutes.
Questionnaire to adolescent students. The Questionnaire before the cycle will be intended to bring out several variables (perceived risk, sensation of practice, interest to the activity, body image and activity value).

a) The students' perception regarding their perceived risk to pole vault practice;

b) The students' sensations to pole vault in general;

c) Their interests to the pole vault lesson;

d) The body image;

e) The activity values.

\section{Results and discussion}

a) Factor analysis: The observation of the factorial structure was determined using the varimax rotation. This analysis concerns the five factors of students' conception of the integration of sports activity, the pole vault, and the school environment. It has been possible to consider that the eigen value is greater than 1 [9], as well as developing $83 \%$ of the total variance. This value is adequate according to [10] (Table 1).

Table 1: Principal component analysis of inquired factors with oblique rotation.

\begin{tabular}{|c|c|c|c|c|c|}
\hline \multicolumn{6}{|c|}{ Factors } \\
\hline $\begin{array}{c}\text { Items Measuring } \\
\text { Students' } \\
\text { Representations }\end{array}$ & Perceived Risk & Sensation & Interest & Body Image & Activity Value \\
\hline $\mathrm{I} 1$ & 0.887 & & & & \\
\hline I2 & 0.776 & & & & \\
\hline I3 & 0.816 & & & & \\
\hline I4 & 0.875 & & & & \\
\hline I5 & & 0.761 & & & \\
\hline I6 & & 0.943 & & & \\
\hline 17 & & 0.944 & & & \\
\hline I8 & & 0.792 & & & \\
\hline I9 & & & 0.96 & & \\
\hline $\mathrm{I} 10$ & & & 0.959 & & \\
\hline I11 & & & 0.963 & & \\
\hline $\mathrm{I} 12$ & & & 0.864 & & \\
\hline $\mathrm{I} 13$ & & & & 0.577 & \\
\hline I14 & & & & 0.691 & \\
\hline $\mathrm{I} 15$ & & & & 0.789 & \\
\hline I16 & & & & 0.8 & \\
\hline I17 & & & & & 0.881 \\
\hline I18 & & & & & 0.888 \\
\hline I19 & & & & & 0.789 \\
\hline $\mathrm{I} 20$ & & & & & 0.876 \\
\hline
\end{tabular}

b) Average internal consistency and correlation between subscales: The results in Table 2 show that the five factors of students' conceptions showing positive saturation values, greater than 0.5 . This is approved by [11]. Results indicate very high average values for sensation factors (pleasure), learner interests, and the value of pole vault activity. But the average 
values associated with the representations and the image of the body are close to the average of the scale. Whereas for the internal consistencies of the five subscales, we find that they vary between 0.78 and 0.84 . Hence the alpha values [12], are acceptable, and this is confirmed by [13].
The results observed in Table 2 determine the nature of correlation between the different subscales, which determine the different components of students' representations of polevaulting sport. Overall, the correlation indices are significant relationships between the five factors studied.

Table 2: Averages, standard deviation, internal consistency and correlation between subscales.

\begin{tabular}{|c|c|c|c|c|c|c|c|c|}
\hline & $\mathbf{9}$ & SD & $\begin{array}{c}\text { Cronbach's } \\
\text { Alpha }\end{array}$ & $\mathbf{1}$ & $\mathbf{2}$ & $\mathbf{3}$ & $\mathbf{4}$ & $\mathbf{5}$ \\
\hline $\begin{array}{c}\text { Perceived } \\
\text { Risk }\end{array}$ & 3.03 & 1.075 & 0.786 & - & & & \\
\hline Sensation & 3.07 & 1.145 & 0.845 & $.421^{* *}$ & - & & \\
\hline Interest & 2.89 & 1.105 & 0.796 & $.637^{* *}$ & $.450^{* *}$ & - & \\
\hline Body image & 3.24 & 1.155 & 0.785 & $.755^{* *}$ & $.464^{* *}$ & $.627^{* *}$ & - \\
\hline Activity Value & 3.53 & 1.094 & 0.834 & $.491^{* *}$ & $.387^{* *}$ & $.496^{* *}$ & $.453^{* *}$ & - \\
\hline
\end{tabular}

\section{Factor validity of the instrument}

The objective of this study was threefold:

a) Determine the confirmation of the questionnaire factor structure and the internal consistency between the five instrument factors for a larger population of students.

b) Validate the relationships between the subscales determined in the first study.

c) Evaluate the influence of gender on student responses in this questionnaire.

\section{Study 2}

\section{Participants and procedure}

The sample was constructed of 361 participants (175 girls and 186 boys), the age varies between 15 and 18 years. They take EPS courses in high school. The procedure for passing the questionnaire is like that used in previous studies. Initially, students responded to the factors measuring risk and feel at the pole vault. In the second stage of the assignment, students were asked to complete the questionnaire measuring the interest of learners in this practice. And finish by answering the questionnaire measuring the value of the activity and the image of the body.

\section{Measures}

This study is based on the construction and validation of questionnaires on students' representations of PSE. As well as theories of students' representations of sports practices.

a) Perceived risks: these are four items (e.g., "Pole vaulting is a very risky sporting activity").

b) Sensations felt during the practice of pole vault: (e.g., "If I practice pole vault, I feel enthusiastic").

c) Interest to the activity of pole vault: (e.g., "a sport that develops, in a global way, my driving ability").

d) Body image: (e.g., "If I practice pole vault, I will have a well-balanced body").

e) Values of the activity: (e.g., "a very useful sport").

The Students' representations questionnaire was expressed on the scale of Likert adapted in five points. [1]: not at all agree, [5]: completely agree.

Table 3:Confirmative factor analysis.

\begin{tabular}{|c|c|c|c|c|c|c|c|c|c|}
\hline $\begin{array}{c}\text { Factor } \\
\text { Loadings }\end{array}$ & $\begin{array}{c}\mathbf{X}^{2} \mathbf{C h i} \\
\text { Square }\end{array}$ & $\mathbf{d f}$ & $\mathbf{X}^{2} / \mathbf{d f}$ & $\mathbf{P}$ & $\mathbf{C F I}$ & NNFI & RMSEA & $\begin{array}{c}\text { RMSEA } \\
{[\mathbf{9 0} \% \text { CI] }}\end{array}$ & SRMR \\
\hline $\begin{array}{c}\text { From } 0.64 \\
\text { to } 0.92\end{array}$ & 231.46 & 87 & 2.66 & $<0.01$ & 0.95 & 0.93 & 0.061 & $\begin{array}{c}{[0.056-} \\
0.076]\end{array}$ & 0.047 \\
\hline
\end{tabular}

Note: RMSEA $(90 \% \mathrm{Cl})=$ Root Mean Square Error of Approximation with Confidence Interval; SRMR = Standardized Root Mean Square Residual; CFI = Comparative Fit Index; NNFI = Non-Normed Fit Index.

\section{Results and discussion}

a) Confirmatory factor analysis and internal consistency of the measurement tool: Confirmatory factor analysis was performed using the Lisrel 8.4 software [14]. Thus, compared to Study 1, there was a concordance in the results obtained in the two studies. However, the hypothetical model suggests that any statement of each factor of the instrument had to fill in their specific confidential variable. As a result, a correlational matrix is obtained that raises the responses examined in terms of observed variables [15]. And therefore, the results confirm the factorial validity of the hypothetical model through (X2, p <.001); (CFI, GFI, EVCI and NNFI, range from 0.91 
to 0.95$)$. As well as RMSEA $=.06$; this is the confidence interval for RMSEA $=.056 / .076$. In addition, the estimated saturation standard coefficients are greater than .62 as well as significant. For the remaining dimensions we can observe some linear significant relations in Table 3. Usually, it is considered that the fit is good when Chi Square/df $<3=$ acceptable; CFI $\geq 0.90=$ good fit; SRMR and RMSEA $\leq 0.08$ = adequate fit) $[16,17]$, and $X 2 / \mathrm{df}<$ 3 [18].

\section{b) Analysis of the temporal reliability of the tool:}

This study has two objectives:

i. Test the temporal fidelity of the instrument.

ii. Confirm the internal consistency of each parameter of the questionnaire.

\section{Study 3}

\section{Participants and procedure}

This study presented 49 volunteers (28 girls and 21 boys). The age of the population varies between 15 and 18 years. They participate in PES lessons. The procedure of passing the questionnaire, like that of previous studies, is repeated twice in a row on the same population. The passing of the second questionnaire, was there after fifteen days after the first one (test 2 = initial test +15 days).

\section{Results and discussion}

The results of the correlational analysis confirmed the temporal stability of the student design measurement tool (Table 3). The Spearman correlation obtained is greater than 0.60 . This was confirmed by an academic study of [19]. The internal consistencies of each factor in the students' conceptions were like those of the observed responses. In addition, these alpha values are between 0.84 and 0.95 . And this confirms the previous studies.

The reliability of the SRQ-S subscales and of each of their items can be esteemed moderate or high (Table 4). The Raykov

Table 5:Students' Representations Questionnaire of Sport (SRQS).
[20] rho composite reliability coefficient of each of its five factors has values ranging between 0.64 and 0.92 [20]. Also, the internal consistency of subscales (perceived risk, sensations, interests, body image and activity value) can be considered moderate or high and are respectively $(0.76,0.89,0.86,0.73$, and 0.92$)$.

Table 4: Reliability and internal consistency between inquired subscales in the test-retest assessment.

\begin{tabular}{|c|c|c|c|}
\hline \multirow{2}{*}{} & \multicolumn{2}{|c|}{$\begin{array}{c}\text { Internal Consistency } \\
\text { Chronbach's Alpha }\end{array}$} & Reliability Test- Retest $\boldsymbol{\rho}$ \\
\cline { 2 - 4 } & T1 & T2 & T1-T2 15 days \\
\hline Perceived Risk & 0.84 & 0.91 & 0.72 \\
\hline Sensation & 0.9 & 0.95 & 0.64 \\
\hline Interest & 0.94 & 0.92 & 0.66 \\
\hline Body Image & 0.92 & 0.89 & 0.68 \\
\hline Activity Value & 0.86 & 0.87 & 0.92 \\
\hline
\end{tabular}

Note: $\rho=$ Raykov's rho coefficient (composite reliability) Test-retest reliability evaluates reliability across time; Internal consistency reliability: It evaluates individual inquiries in comparison with one another for their ability to give consistently appropriate results.

\section{Conclusion}

Our findings show important properties of validity and reliability of students' representations questionnaire to specific sport. First, consistency of questions of representation may be well estimated in the questionnaire summarizing the perceived five subscales for the dichotomy of questions. Second, Items of the questionnaire were filtered to twenty statements as reliable measure of a specific sport preferred. Third, reliability of the attitudinal scales was substantially acceptable. Reliability is an important part of the questionnaire validation and highlight applicability of the questionnaire.

\section{Limitations of the Present Work}

A limitation of this work consists in the needs to generalization of our findings to wide population or regions, for achieving more reliability. Another limit of this study might be related to the student motivation profile $[21,22]$ or his attraction to some sports (Table 5).

\begin{tabular}{|c|c|c|c|c|c|}
\hline Items et Sous-échelles Mesurant les Représentations des Élèves & 1 & 2 & 3 & 4 & 5 \\
\hline \multicolumn{6}{|l|}{ Risque Perçu } \\
\hline \multicolumn{6}{|l|}{ 1) La pratique de ce sport est risquée, mais je peux me protéger } \\
\hline \multicolumn{6}{|l|}{ 2) J'ai souvent la répugnance et la paresse à l'effort physique } \\
\hline \multicolumn{6}{|l|}{ 3) Ce sport est une activité dangereuse } \\
\hline \multicolumn{6}{|l|}{ 4) La pratique de ce sport est risquée } \\
\hline \multicolumn{6}{|l|}{ Sensation à la Pratique } \\
\hline \multicolumn{6}{|l|}{ 5) J'éprouve de plaisir et de la satisfaction à apprendre des nouvelles techniques de cette pratique } \\
\hline \multicolumn{6}{|l|}{ 6) Je m'oublie en pratiquant ce sport et je vois toujours la séance pratique un bon moment } \\
\hline \multicolumn{6}{|l|}{ 7) Cette activité me permet de sensations uniques } \\
\hline \multirow{2}{*}{\multicolumn{6}{|c|}{ 8) Cette pratique sportive est très spectaculaire }} \\
\hline \multicolumn{2}{|l|}{ Intérêt à l'Activité } & & & & \\
\hline 9) Il est plus important de savoir faire ce sport, plutôt que de pratiquer des tâches motrices faciles & & & & & \\
\hline
\end{tabular}


Annals of Reviews and Research

10) Cette activité est le moyen que je choisi pour acquérir des habilités dans d'autres sports

11) Si j'étudie sport, je pourrais développer beaucoup de compétences motrices

12) Avec cette pratique, j'ai la meilleure façon pour éliminer les tensions

\section{Image du Corps}

13) Je suis satisfait de mon corps

14) Globalement, je suis fier de mes capacités physiques

15) Je me sens mieux physiquement, si je pratique ce sport particulier

16) Je ne me sens pas bien physiquement sur ce que je peux faire avec ce sport

\section{Valeur de l'Activité}

17) J'aime vraiment cette pratique particulière

18) Ce sport peut mieux développer mes qualités physiques

19) Je pense que la pratique de cette activité nécessite plus de concentration et de confiance

20) Je pense qu'avec ce sport, le contrôle des mouvements de mon corps sera mieux amélioré

Note: [1]: Not at all agree; [2]: Slightly agree; [3]: Moderately agree; [4]: Agree; [5]: Completely agree

\begin{tabular}{|c|c|c|c|c|}
\hline Pas du tout en Accord & Légèrement en Accord & Moyennement en Accord & En Accord & Complètement en Accord \\
\hline 1 & 2 & 3 & 4 & 5 \\
\hline
\end{tabular}

Encercler un chiffre entre 1 (Pas du tout en accord) et 5(Complètement en accord) / [Circle one number between 1 (Not at all agree) and 5 (completely agree)]. I prefer to practice the sport of "Name of Sport" because... / [Je préfère pratiquer le sport du "Nom du Sport" parce que...]

\section{References}

1. Moscovici S (1961) La psychanalyse, son image et son public. Paris : PUF.

2. Kovacs GT, Morgan G, Levine M, McCrann J (2012) The The Australian community overwhelmingly approves IVF to treat subfertility, with increasing support over three decades. Aust N Z J Obstet Gynaecol 52(3): 302-304.

3. de Lacey SL, Peterson K, McMillan J (2015) Child interests in assisted reproductive technology: how is the welfare principle applied in practice? Hum Reprod 30(3): 616-624.

4. Silverman D (2011) Interpreting Qualitative Data. ( $4^{\text {th }}$ edn), London, UK, Sage.

5. Chedzoy SM, Burden RL (2007) Marking Time or Moving on: Student Perceptions of School Life in Year 8 and Their Attributions for Their Success and Failure in Learning. Research in Education 77(1): 31-45.

6. Derbali C, Elloumi A, Matoussi F (2017) Reflections and Conceptions Analysis of the Neosphere's Actors on Teaching Pole Vault Activity throw Physical Education Program. International Research Journal of Curriculum and Pedagogy 3(2): 52-58.

7. Derbali, C, Matoussi F, Elloumi A (2018) Curriculum Method Grounded on Didactic Engineering to Expertise Physical Education Program Proposal. Journal of Education and Practice 9(31): 49-59.

8. Brune MW, Benson AJ (2018) Evaluating the psychometric properties of the Social Identity Questionnaire for Sport (SIQS). Psychology of Sport and Exercise (35): 181-188.

9. Guttman L (1954) Some necessary conditions for common factor analysis. Psychometrika 19(2): 149-161.

10. Gorsuch RL (1983) Factor analysis $2^{\text {nd }}$ (edn.), Erlbaum, Hillsdale, NJ, USA.

11. Conroy WG, Liu Z, Nai Q, Coggan JS, Berg DK (2003) PDZ-Containing Proteins Provide a Functional Postsynaptic Scaffold for Nicotinic Receptors in Neurons. Neuron 38(5): 759-771.
12. Cronbach LJ (1951) Coefficient Alpha and the Internal Structure of Tests. Psychologist (37): 122-147.

13. Nunnally JC (1978) Psychometric Theory. McGraw-Hill, New York, USA.

14. Jöreskog KG, Sörbom D (1993) LISREL 8 [Computer software]. Scientific Software International Inc, Chicago, IL, USA.

15. Chou CP, Bentler PM (1995) Estimates and Tests in Structural Equation Modeling. In Rick H (Ed.), Structural equation modeling: Concepts, issues, and applications. Sage Publications Inc, Thousand Oaks, CA, USA, pp. 37-55.

16. Schermelleh-Engel K, Moosbrugger H, Müller H (2003) Evaluating the Fit of Structural Equation Models: Tests of Significance and Descriptive Goodness-of-Fit Measures. Methods of Psychological Research 8(2): 23-74.

17. Hu L, Bentler PM (1999) Cutoff criteria for fit indexes in covariance structure analysis: Conventional criteria versus new alternatives. Structural Equation Modeling: A Multidisciplinary Journal 6(1): 1-55.

18. Ruiz MA, Pardo A, San Martín R (2010) Modelos de ecuaciones estructurales [Structural equation models]. Papeles del Psicologo, 31(1): 3445.

19. Duda J L, Whitehead J (1998) Measurement of Goal Perspectives in the Physical Domain. In : Duda J (Eds.), Advances in Sport and Exercise Psychology Measurement, Fitness Information Technologies, Morgantown, WV, USA, pp. 21-48.

20. Raykov T (1997) Estimation of composite reliability for congeneric measures. Applied Psychological Measurement 21(2): 173-184.

21. Derbali C, Elloumi A, Matoussi F (2015) Didactics of Physical Education : The Case of Motivational students Profiles in Pole Vaulting Performance. Creative Education 6 (12): 1349-1359.

22. David ÁG, José CN, Alejandra BC, Trinidad G (2017) Validation of the Cybervictimization Questionnaire (CYVIC) for adolescents. Computers in Human Behavior 70: 270-281. 


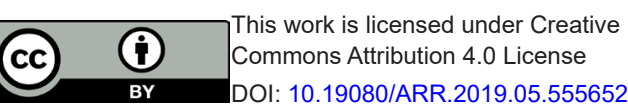

Your next submission with Juniper Publishers will reach you the below assets

- Quality Editorial service

- Swift Peer Review

- Reprints availability

- E-prints Service

- Manuscript Podcast for convenient understanding

- Global attainment for your research

- Manuscript accessibility in different formats ( Pdf, E-pub, Full Text, Audio)

- Unceasing customer service

Track the below URL for one-step submission https://juniperpublishers.com/online-submission.php 